\title{
8
}

\section{NILAI ESTETIS BATIK GARUT PEGUNUNGAN DAN PESISIR}

IRAADRIATI

Received: 14 September 2019; Accepted: 23 Oktober 2019; Published: 5 November 2019

Ed. 2019; 3 (1): 075 - 081

\begin{abstract}
Abstrak
Batik is a result of a tradition of ownership owned by various regions in Indonesia. One of the areas in West Java is known as Batik Priangan, including the region of Garut. Each region in Priangan has a batik that is batik with unique motifs and coloring in each region. In this paper, it describes the aesthetic value of batik Garut in the mountainous areas with the coastal areas. This research uses historical approach, the value of tradition-oriented, and in cultural acculturation. Based on the analysis, it can be known that the waters can be different from the visualization of batik motifs in the mountainous regions, which tend to be classic motifs, typical of the late night and the coast of the region. The other difference appears from the ability of the craftsmen, the craftsmen in the mountainous regions show more detailed and smooth skills, while on the coast there is no detail.
\end{abstract}

Kata kunci: batik, Garut, mountainous areas, coastal.

\section{PENDAHULUAN}

Budaya Sunda mendapat pengaruh dari Budaya Jawa, terutama pada saaat berada di bawah kekuasaan Mataram selama hampir tig aabad, dari sekitar 1600 sampai dengan 1900-an. Para bupati yang dipilih atau ditempatkan Mataram di Jawa bagian barat adalah faktor penting yang sangat menentukan dari proses asimilasi budaya Jawa. Para Bupat itersebut dengan mudah memberlakukan bukan hanya sistem politik Jawa yang menguntungkan mereka, tetapi juga sistem kebudayaan Jawa. Pengaruh budaya yang sangat terasa adalah penggunaan tingkatantingkatan dalam Bahasa Sunda yang terpengaruh oleh Bahasa Jawa, selain itu penggunaan pakaian 'Jajawaan' yang dikenakan oleh menak atau ningrat di Sunda. Pakaian 'Jajawaan' tersebut termasuk penggunaan batik di dalamnya (39). Batik di Jawa bagian Barat berkembang seiring dengan proses akulturasi dengan Jawa bagian Tengah, kecuali Cirebon yang berkembang bersama dengan perbatikkan di daerah pesisir lainnya di Pulau Jawa. Batik non pesisir dari pulau Jawa bagian Barat ini kemudian dikenal dengan sebutan 'Batik Priangan' (27) Batik Priangan adalah istilah yang digunakan untuk memberikan identitas pada berbagai batikan yang dihasilkan dan berlangsung di Priangan, daerah di wilayah Jawa Barat dan Banten yang penduduknya berbahasa dan berbudaya Sunda. Nama Priangan berasal dari kata "parahyangan", yang bermakna "warga khayangan" atau "tempat para Dewa“. Melalui penuturan tersebut Priangan memiliki arti simbolis, yakni tempat tinggal para Dewa (5). Simbolis tersebut selalu dikaitkan dengan alam atau bentang geografis wilayah Priangan yang terlihat subur dan indah.

\section{METODOLOGI}

Dalam penelitian ini menggunakan metode analisis kualitatif. Menggunakan teori seni rupa tradisi Nusantara khususnya konsep batik dari 
Jakob Sumardjo, teori difusi budaya. Menurut Jakob Sumardjo batik merupakan produk pemikiran manusia sawah dapat disimak dari motif-motif yang merupakan symbol kosmologi mereka. Bukti otentik itu terletak pada simbolsimbol gambar batiknya. Di samping itu dapat terlihat pada lembaran kain yang dibakukan untuk dibatik. Proses pembatikan itu sendiri dibaca sebagai bentuk proses ritual yang tidak berani dilanggar oleh pembuat batik. Fungsi batik sendiri berkaitan dengan berbagai upacara dalam rangkaian kehidupan manusia. Batik juga hanya boleh dibuat oleh perempuan karena unsur kain yang digunakan bagi manusia primordial merupakan symbol dari perempuan (SUMARDJO, 2014, 340).

Berdasarkan pemikiran EDWARD B. TYLOR yang menyebutkan bahwa unsur kebudayaan dapat tersebar dari satu masyarakat ke masyarakat lainnya dengan cara yang disebut difusi yaitu peminjaman suatu unsur kebudayaan dari kebudayaan lainnya sebagai akibat dari adanya kontak antar kedua kebudayaan (IHROMI, 2016, 69). Metode pengumpulan data melalui kaji pustaka dan observasi langsung ke Museum Tekstil Jakarta.

\section{Perkembangan Batik Garut}

Garut merupakan kawasan di Jawa Barat yang memiliki karakter geografis pegunungan sekaligus laut yang berada di Pesisir Selatan Pulau Jawa berhadapan dengan Samudra Hindia. Akses utama menuju Garut melalui jalan darat. Oleh karena itu kebudayaan-kebudayaan baru masuk melalui jalur pegunungan. Karakter geografis Garut pegunungan dikenal dengan istilah Swiss van Java karena cuacanya yang nyaman serta pemandangannya yang indah.

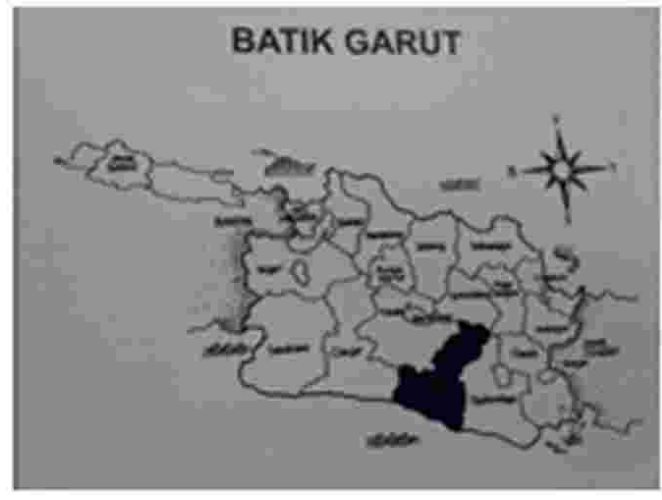

Gambar 1. Lokasi Garut Sumber: Kudiya, 2013.

Berdasarkan sumber data lainnya diketahui bahwa kegiatan membatik telah berlangsung sejak masa abad ke-19. Beberapa bukti melalui foto di bawah ini memperlihatkan kegiatan membatik yang dilakukan oleh perempuanperempuan Garut di lahan-lahan perkebunan seperti di daerah perkebunan Waspada pada tahun 1875 maupun foto perempuan yang sedang membatik pada tahun 1920. Selain itu penggunaan kain batik untuk kepentingan keseharian terlihat dari foto yang memperlihatkan aktifitas perempuan di pasar mereka menggunakan kain batik sebagai pakaian mereka. Hal tersebut mempertegas bahwa di wilayah Garut, kegiatan membatik merupakan kegiatan yang umum. Penggunaan kain batik di masyarakatnya mempertegasakan keberadaan pengrajin batik di Garut.

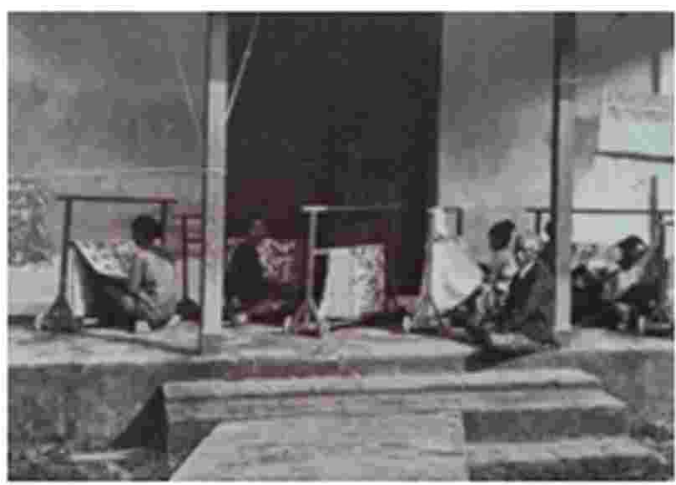

Gambar 2.Pembatik Garutdi Daerah Perkebunan WaspadaTahun 1875 Sumber: Natanegara \& Achjadi, 2012. 


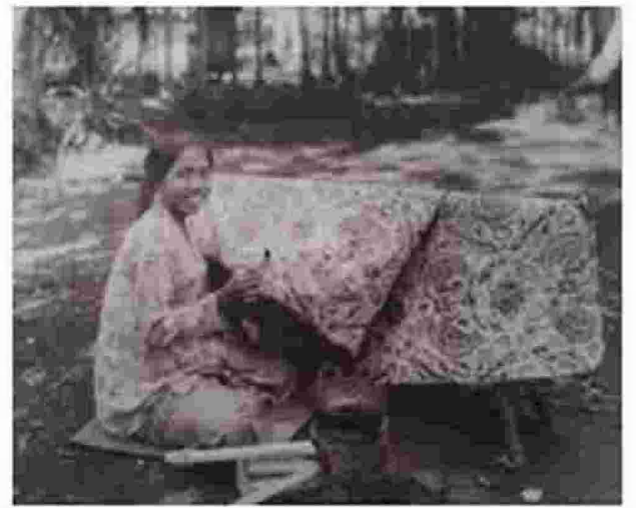

Gambar 3. Pembatik Garut Tahun 1920

Sumber: Natanegara\&Achjadi, 2012.

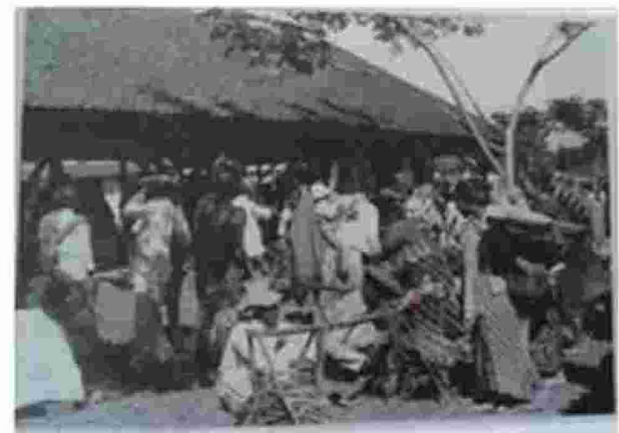

Gambar 4. Suasana Pasar di Garut Sekitar Tahun 1930-an, Terlihat Perempuan Menggunakankain Batik Sumber: Natanegara \& Achjadi, 2012.

Motif Batik Garut sangat beragam terdapat motif-motif yang memperlihatkan kesinambungan atau akulturasi dengan berbagai kawasan seperti batik keratin dari Surakarta atau Yogyakarta, maupun batik yang berasal dari kawasan pesisir pantai utara seperti kawasan Pekalongan dan Cirebon. Motif Batik Garut yang terlihat klasik seperti Batik Rereng. Selanjutnya pengrajin batik di Garut memperlihatkan kreatifitasnya dengan menambahkan unsur-unsur hewan, tumbuhan, maupun artefak lainnya yang ditemukan di Garut. Di kawasan Pesisir Selatan Garut berkembang motif yang dibuat dengan menampilkan binatang-binatang laut yang terlihat pada motif Aquarium. Warna-warna yang digunakannya menyolok dan berbeda dari warna khas batik Garut yaitu kream dan putih gading dengan warna coklat tanah kemerahmerahan.

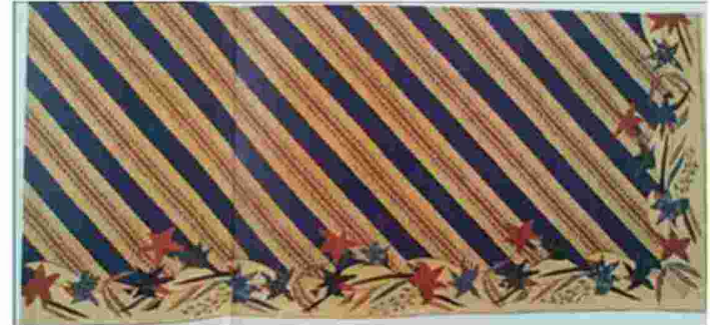

Gambar 5. Motif Parang Gandengtahun 1950 Sumber: Natanegara \& Achjadi, 2012, 86).

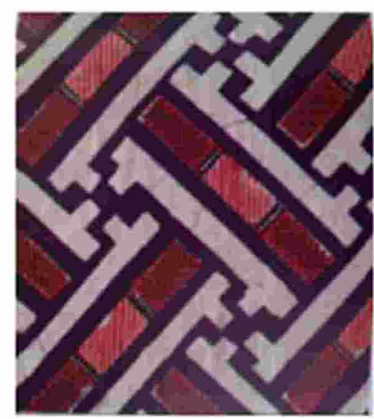

Gambar 6. Motif Angkin Garut Sumber: Kudiya, 2013.

Salah satu motif batik Garut yang terkenal adalah motif bilikatau motif dinding dari bamboo. Motif ini awalnya berwana coklat khas batik Garutan, kemudian berkembang dengan penambahan motif bunga seperti bagian dari motif buketan Pekalongan, dengan warna-warna yang beragam bahkan menyerupai keragaman batik Belanda atau Batik Encim. Contoh motif batik tersebut seperti terlihat di bawah ini.

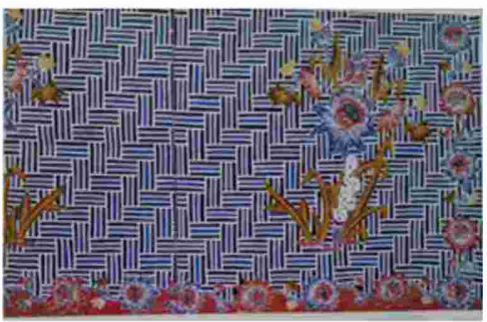

Gambar 7. Motif Bilik Papangkah Sumber: Pradito, Jusuf, \& Atik, 2010.

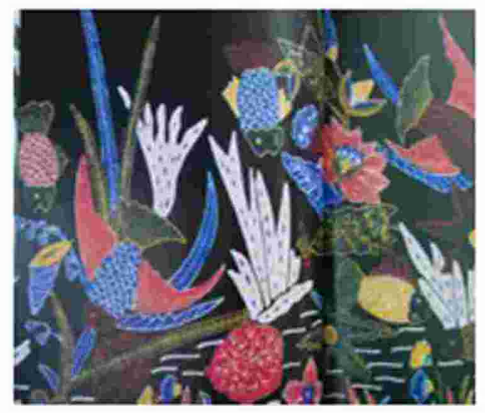

Gambar 8. Batik Garut Pesisir Motif Aquarium Garut Sumber: Kudiya, 2013. 
Terdapat pula keinginan menjadikan kain batik serupa dengan kanvas. Muncul motif batik Pajajatan yang memperlihatkan visualisasi kereta kencana yang dinaiki oleh raja serta diiringi oleh para prajurit serta penasehatnya. Motif tersebut tampak pada motif Pajajaran di bawah ini. Warna yang digunakan masih menggunakan warna yang tidak menyolok yaitup utih, coklat, dan biru tua.

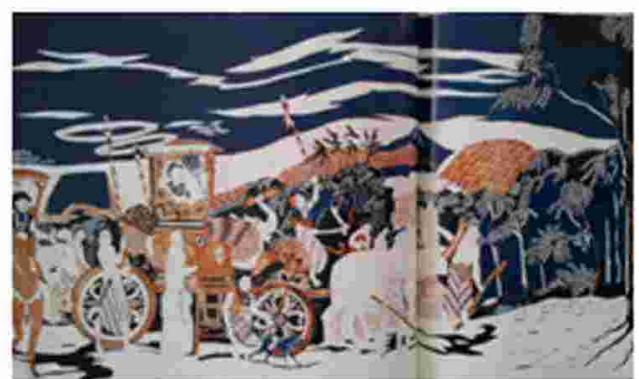

Gambar 9. Batik Pajajaran Sumber: Pradito, Jusuf, \& Atik, 2010.

\section{Analisis Nilai Estetis Batik Garut}

\section{Pegunungan dan Batik Garut Pesisir}

Di bawah ini akan dianalisis perbedaan antara motif batik yang dibuat di sentra batik Garut yang terletak di kawasan pegunungan atau pusatpusat batik awal dan utama di Garut, dengan batik yang dikerjakan di kawasan pesisir selatan Garut yang berhadapan dengan laut Pantai Selatan (Samudra Hindia).

Batik di daerah Pegunungan memperoleh pengetahuan batik dari kawasan Jawa bagian Tengah yang berasal dari Keraton Surakarta maupun Yogyakarta. Selain itu pengaruh dapat pula berasal dari kawasan Pantai Utara Jawa seperti Pekalongan dan Cirebon. Hal ini terlihat dari motif yang kemudian digunakan dalam batik Garut.

Kawasan Pesisir Selatan yang berhadapan langsung dengan Samudra Hindia, memperoleh keterampilan membatik dari kawasan Batik Garut Pegunungan. Hal tersebut karena tidak memungkinkan adanya pendatang yang masuk melalui jalur laut selatan dengan ombak-
Dalam proses analisa akan diambil dua sampel motif batik Garu tyaitu Merak Ngibing dan Motif Batik Mojang Priangan. Motif MerakNgibing merupakan salah satu motif khasdari Garut, demikian pula Motif Mojang Priangandi kenal sebagai motif yang berkembang di Garut.

\section{Motif MerakNgibing (Menari)}

Duakain batik yang pertama dikerjakan oleh pengrajin di Pegunungan atau istilah untuk membedakan dengan batik yang dibuat oleh pengrajin di Pesisir. Melalui visualisasi terlihat bagaimana detailny abentuk merak yang distilasi. Pada motif Merak ngibing bagian atas berwarna biru sedangkan pada bagian bawah berwarna kecoklatan. Untuk Batik coklat menggunakan motif dari renda pada masa kolonial pada bagian bawah kain. Menyerupai renda pinggiran kain masyarakat Eropa abad ke 18. Motif merak yang digunakan seakan-akan saling berhadapan menyilang, memperlihatkan Gerakan yang mesra. Batik pertama menggunakan warna biru dan coklat jingga. Terlihat pengulangan motif dengan bagian ujung kain terdapat motif tumpal kecil. Pengerjaan keduanya sangat detail dengan garis-garis halus.

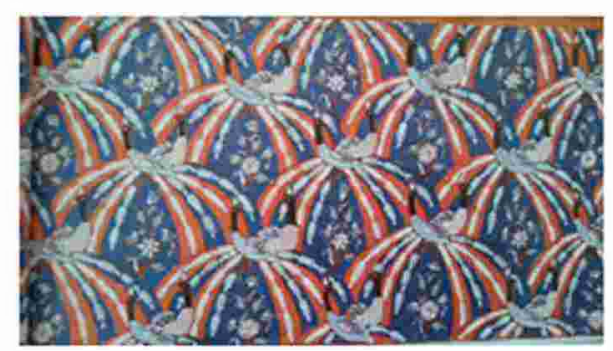

Gambar 10. Merak Ngibing Sumber: Pradito, Jusuf, \& Atik, 2010.

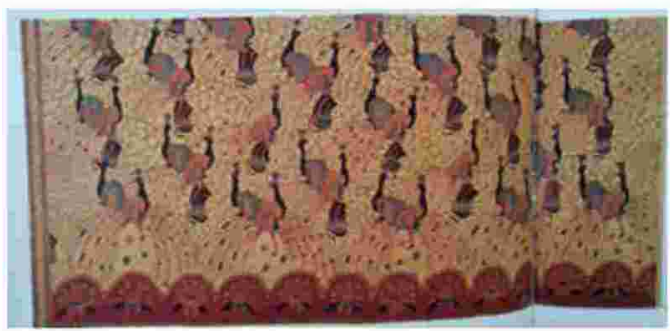

Gambar 11. Merak Ngibing Sumber: Natanegara \& Achjadi, 2012, 86. 
Pada Kain Batik Motif Merak Ngibing yang dibuat di Pesisir Garut memperlihatkan penggunaan warna yang ringan. Pada batik pertama dipadukan dengan motif lain. Nama Motif tersebut menjadi Motif Pegat Maru latar Rereng Kembang. Burung merak ditempatkan hanya pada bagian bawah. Berbeda dengan motif klasik Merak Ngibing.

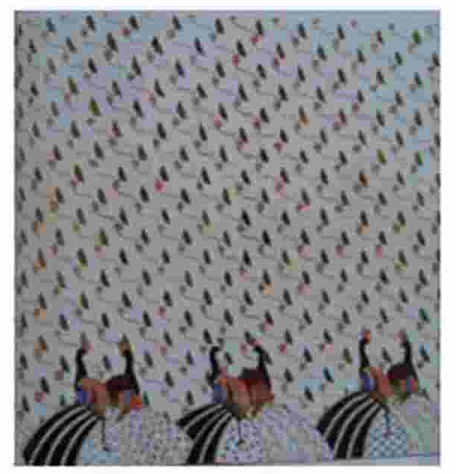

Gambar 12. Merak Ngibing Pesisir Garut Sumber: Kudiya, 2013.

Motif Merak Ngibing kedua masih memperlihatkan keserupaan dengan motif khas Merak Ngibing yang dibuat di Pegunungan. Hanya saja jika diperhatikan secara seksama, telah kehilangan detail-detail pada bagian ekor merak, demikian pula pada bagian tubuh merak itu sendiri seakan-akan hanya memblok warna hitam. Secara keseluruhan terdapat penurunan kualitas pada motif Merak Ngibing di daerah Pesisir Selatan Garut.

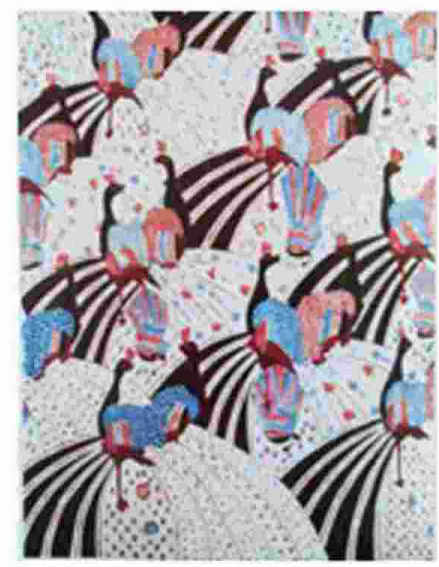

Gambar 13. Merak Ngibing Pesisir Garut Sumber: Kudiya, 2013
Berdasarkan pemaparan di atas terlihat adanya penurunan kemampuan melukiskan motif Merak Ngibing di kawasan Pesisir Selatan Garut. Penggunaan warna pun menjadi lebih ringan dan tidak terlihat menutupi. Pada motif batik Merak Ngibing yang dipadukan dengan motif Rereng Kembang terlihat inovasi menarik penggabungan dua motif tersebut, terlihat lebih ringan pemilihan warnanya serta kesan khas Garut masih Nampak dari penggunaan warna gading yang dominan.

\section{Motif Mojang Priangan}

Motif lainnya yang menjadi sampel adalah motif Mojang Priangan. Motif ini jika dicermati sebenarnya menyerupai dengan motif kain encim dari Pekalongan. Dari sampel yang pertama yang diaplikasikan pada kain sarung sangat identik, tetapi masyarakat pengrajin batik menyebutnya dengan nama Mojang Priangan. Obyek yang menyusun motif adalah stylasi bunaga, kupu-kupu, dan merak. Terlihat komposisi yang feminine, mengingatkan pada bentuk stilasi periode Islam di kawasan'Turki. Warna yang dipilih cenderung berkesan lembut dan cantik, serta pengerjaan yang detail.

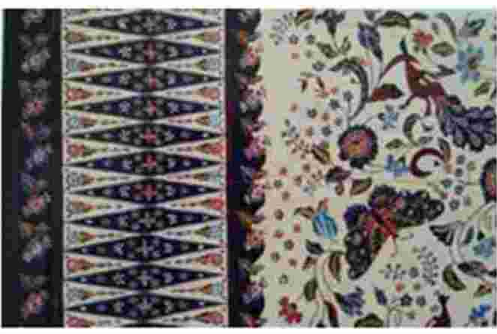

Gambar 14.

Batik Garut Pegunungan Motif Mojang Priangan Sumber: Pradito, Jusuf, \& Atik, 2010.

Sampel kedua yang berasal dari pegunungan ini masih menggunakan warna-warn aserupa dengan sample sebelumnya, latar putih menambah kesan cerah. Setiap obyek yang dilukiskan terlihat detail dan selintas serupa dengan jenis kain buketan. Terdapat motif yang serupa, tetapi dengan penggunaan warna yang berbeda seperti terlihat pada bagian meraknya, menggunaan warna merah muda dan warna kuning. 


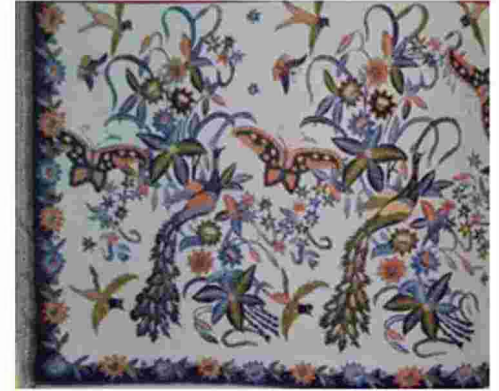

Gambar 15.

Batik Garut Pegunungan Motif Mojang Priangan

Sumber: Pradito, Jusuf, \& Atik, 2010.

Dua sampel berikutnya merupakan Motif Mojang Priangan yang dikerjakan di kawasan Pesisir Garut. Pada kain batik pertama masih terlihat keserupaan dengan motif yang dikerjakan di pegunungan. Pemilihan warnanyapun cendrung serupa dengan latar putih. Hanya saja tidak sedetail bentuk yang dibuat di Pegunungan.

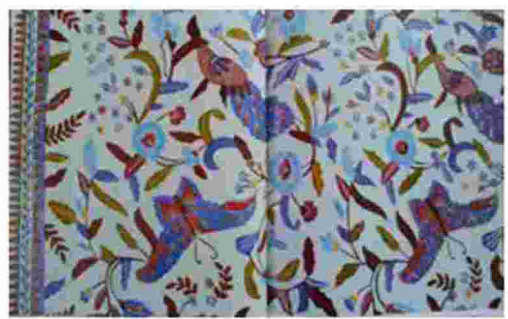

Gambar 16.

Batik GarutPesisir Motif Mojang Priangan Klasik Latar Lepaan Bodas Gumading (putih kekuningan) Sumber: Kudiya, 2013.

Motif Batik Mojang Priangan sampel kedua terlihat masih menggunakan obyek burung merak dan bunga, tetapi semakin jauh dari detail motif sebelumnya. Motif bunga seakan-akan serupa dengan motif yang dikerjakan di daerah Pesisir Utara Jawa Barat yaitu di Cirebon dan Indramayu. Penggunaan warna merah sebagai warna dasar pun memperlihatkan bahwa batik ini merupakan batik baru untuk motif batik Mojang Priangan. Walaupun terdapat penurunan kualitas, tetapi terlihat usaha pengrajin untuk mengikuti selera masyarakat akan warna-warna yang cerah.

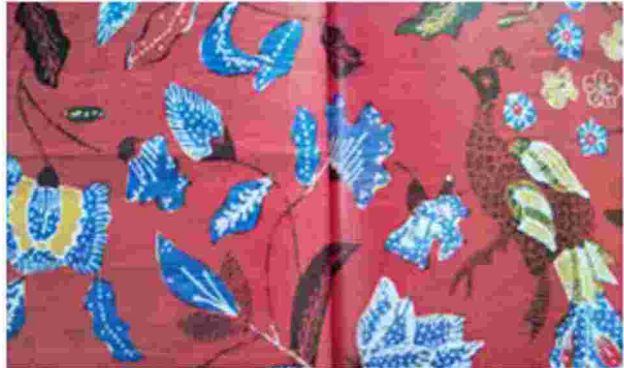

Gambar 17. Batik Garut Pesisir

Motif Mojang Priangan Latar Beureum (Merah) Sumber: Kudiya, 2013.

\section{KESIMPULAN}

Berdasarkan hasil penelitian mengenai nilai estetis Batik Garut Pegunungan dan Batik Garut Pesisir dalah sebagai berikut:

1. Adanya perbedaan visualisasi motif batik di daerah Pegunungan cenderung motif-motif klasik khas Garut dengand aerah Pesisir Garut yang lebih banyak mengembangkan motif aktual.

2. Perbedaan pewarnaan di antara batik Garut pegunungan yang lebih lembut menggunakan warna cenderung kream sedangkan di pesisir lebih banyak menggunakan warna menyolok.

3. Perbedaan lainnya tampak dari kemampuan teknik pengrajinnya, pengrajin di daerah pegunungan lebih memperlihatkan keterampilan membatik sangat detail dan halus, sedangkan di Pesisir terlihat tidak detail.

\section{UcapanTerima Kasih}

Terima kasih kepada pihak Institut Teknologi Bandung melalui Program P3MI 2019 yang telah memfasilisasi program penelitian batik nusantara.

\section{DAFTAR PUSTAKA}

IHROMI, T.O.

2016. Pokok-pokok Antropologi Budaya, keempat belas, Yayasan Pustaka Obor Indonesia, Jakarta. 
Kudya, K, ED.

2013. Batik Pesisir Selatan Jawa Barat, Jalasutra, Yogyakarta.

NAtanegara, B.A. \& ACHJADI, J.IK. 2012. Dunia Batik SeorangJustin, red and white Publishing, Jakarta.

Pradito, D., Jusuf, H., Atik, S.IK. 2010. The Dancing Peacok: Colours and Motifs of Priangan Batik, Gramedia Utama, Jakarta.

SUNARYA, Y.

2019. Tapak Batik Sunda dalam Tapak Seni Rupa Nusantara, Penerbit ITB, Bandung.

SumARDJO,J.

2014. Estetikea aradoks, Kelit, Bandung. 